\title{
LIABILITY FOR INDEPENDENT CONTRACTORS IN CONTRACT AND TORT: Duties to ENSURE THAT CARE IS TAKEN
}

\section{JONATHAN MORGAN}

B engages an independent contractor, C. C negligently injures A. Can A sue B for the harm caused by the contractor (assuming that B is himself blameless)? When $\mathrm{A}$ has a contract with $\mathrm{B}$ he will normally be able to recover (depending ultimately on the terms of the contract). But not in tort. Only if B's duty is (exceptionally) "non-delegable" must he answer for C's negligence (outside torts of strict liability, such as Rylands $v$ Fletcher). This article explains the doctrinal cogency of that elementary distinction between contract and tort. It warns against drawing simple analogies between them (especially to justify liability in tort by considering B's liability had a hypothetical contract existed between A and B). This aspect of the recent decision in Woodland v Swimming Teachers Association is criticised accordingly. ${ }^{1}$ Drawing analogies might appear to be a simple common sense matter, and indeed the foundation of the common law technique. But it is in fact no value-neutral exercise, whether in private law or high constitutional matters. ${ }^{2}$ Moreover, doctrinal reasoning can take us only so far. There are bigger questions lurking here. In the space of this article (with its primary focus on the doctrinal differences between contract and tort) we can only identify those bigger questions, and not provide final answers to them. The immanent controversy arises from the increasingly common use of independent contractors ("outsourcing") in the modern economy. This social phenomenon raises questions about the traditional limitation of vicarious liability to the employment relationship. To date there has been little appetite for questioning the axiom that there is no vicarious liability for independent contractors. It should now be openly debated. This article clears the ground for that consideration to proceed.

\section{WOODLAND V SWIMMING TEACHERS ASSOCIATION}

Miss Woodland was injured during a swimming lesson organised as part of the curriculum at her state primary school - allegedly due to negligent supervision by the lifeguard on duty at a pool belonging to a local authority (Basildon Council) other than the one responsible for the claimant's school (Essex County Council). Basildon had outsourced provision of lessons and lifeguard services to an independent contractor (Direct Swimming Services). Miss Woodland claimed against the lifeguard, the contractor, their common insurer (the first named defendant), and against both local authorities. On the bare facts, any claim against the authorities was destined to fail unless they owed the claimant a "non-delegable duty" rendering them liable for the contractor's negligence. Differing from the courts below, the Supreme Court identified such a "non-delegable duty" and declined to strike the claims out.

Lord Sumption identified the claim as one falling under a second general heading of "non-delegable duties" in English law (i.e. not the much-criticised category of "inherently hazardous operations"). Namely where, pursuant to an "antecedent relationship" between the parties,

\footnotetext{
${ }^{*}$ Corpus Christi College, Cambridge CB2 1RH. I am grateful to Richard Wilmot-Smith Q.C., Prof. Steve Hedley, Donal Nolan and members of the Oxford Obligations Discussion Group for generous comments on earlier versions of this paper. Naturally, they cannot be taken to approve the arguments that follow.

${ }^{1}$ [2013] UKSC 66; [2014] A.C. 537 (Woodland).

${ }^{2}$ Cf. R. Dworkin, Justice in Robes (Cambridge, Mass. 2006), 69: "Is abortion more like infanticide or appendectomy? We cannot even begin to answer those questions without a deep expedition into theory".
} 
the defendant is assuming a liability analogous to that assumed by a person who contracts to do work carefully. ... The analogy with public services is often close, especially in the domain of hospital treatment in the National Health Service or education at a local education authority school, where only the absence of consideration distinguishes them from the private hospital or the fee-paying school performing the same functions under contract. ${ }^{3}$

Lord Sumption further reasoned that as fee-paying schools' responsibilities "are already nondelegable because they are contractual", there was "in this particular context ... no rational reason why the mere absence of consideration should lead to an entirely different result when comparable services are provided by a public authority". ${ }^{4}$ His Lordship similarly criticised "the technical distinctions that would otherwise arise between privately funded and NHS hospital treatment". ${ }^{5}$

Most would feel instinctive sympathy with an innocent child's severe injuries. That makes the result in Woodland hard to criticise. But the reasoning is not unproblematic. It is questionable whether the local authorities had really "voluntarily assumed responsibility" for the way that the contractors taught the claimant to swim, let alone for the contractors' solvency. Moreover, the advantageous position of claimants suing private schools and hospitals in contract does not of itself justify the extension of public service providers' liability in tort. People can always in principle bargain for greater rights (including protection against injury) through a contract. Potential contractual liability can hardly then be a guide for the limits of tort (it would essentially abolish any limits). The proper relationship between contract and tort is controversial, and historically fluid. Stated very crudely, the prevailing view today is that tort should set the baseline of safety that everyone is entitled to expect, irrespective of payment. People are free to use their wealth to purchase additional services (including higher standards of care) if they like. But if consumers have to pay to get reasonable care - if payment is not merely for luxuries ("optional extras") — we face the "uncomfortable" feeling that the tort baseline falls unacceptably short. ${ }^{6}$ Criticism of the (over-)advantageous position of contracting parties in fact expresses dissatisfaction with the inadequacy of tort. Tort would then need to reassess its own contours of liability, without the argument (which always proves too much) that paying consumers might have more extensive rights of action under contract. Liability for breach of contact is usually strict - is that unfair on tort claimants who are usually required to prove fault?

\section{CONTRACT AND TORT}

There are many situations where liability is quite unproblematic in contract (e.g. for omissions, for pure economic loss) while controversial in tort. Many have argued for the expansion of tort liability in these areas, for various reasons. But few before Woodland passed from the trite observation that, had a contract existed between the parties, the defendant would have been liable to assert that therefore there must be liability in tort. Such reasoning seems dubious. Within the outer limits of public policy (e.g. illegality), there are few obligations that cannot be deliberately created by a suitably drafted contract. If tort liability always tracked the potential liabilities that parties could have created by contracting (although they actually did not contract),

\footnotetext{
${ }^{3}$ Woodland [7].

${ }^{4}$ Woodland [25] (5) (similarly at [29]-[34] per Baroness Hale).

${ }^{5}$ Ibid.

${ }^{6}$ P.S. Atiyah, "Medical malpractice and the contract/tort boundary" (1986) 49 Law \& Contemporary Problems 287, 297.
} 
it would know virtually no bounds. This limitless expansion of tort would make much contracting redundant. Why contract for (and pay for) an obligation that the law of torts anyway imposes on the prospective promisor? ${ }^{7}$

That last statement might be thought to prove too much. Is it not always the case that tort liability gives claimants "free" what they would otherwise had to have paid (contracted) for? Blanket disapproval of such "free-riding" leads directly back to the $19^{\text {th }}$ Century world of very limited tort liability. Far from the post-Donoghue v Stevenson presupposition that we are all entitled to expect reasonable care from our neighbour, "in the period of classical contract law [c. 1770-1870], a right to due care was still largely seen as something for which [people] had to pay".

"In classical law it was clear that the promise principle was not merely an affirmative principle of liability, but also an exclusionary principle of no liability. In general, if you promised, you were liable, but if you did not promise, then conversely you were not liable... Nor was this exclusionary function of promising purely the result of formalism or of limited vision. It reflected an ideological commitment to the respect for individual autonomy..."

Winterbottom $v$ Wright was not flawed by a logical fallacy that "escaped the perspicuity of judges like Abinger C.B." only to be "brilliantly exposed" in Donogue v Stevenson. ${ }^{10}$ That familiar fable ("what passes for legal reasoning in students' textbooks") is "almost complete nonsense"; the court in Winterbottom relied on policy, not (fallacious) doctrinal "logic". ${ }^{11}$ Only the customer who paid for the goods should be entitled to sue the manufacturer in respect of defects, they reasoned. It looks one-sided today: what about the competing policy of consumer protection for injured bystanders? But Donoghue $v$ Stevenson represents a policy choice-ultimately an "ideological commitment" - as much as the Court of Exchequer's in Winterbottom v Wright. The shift from contract to tort was "essentially designed to be redistributive". ${ }^{12}$

Atiyah hailed the "Fall of Freedom of Contract" in the mid-20 $0^{\text {th }}$ Century (prematurely, as he came to admit). But tort liability has certainly expanded. The universal duty to exercise due care was couched in moral (indeed Biblical) terms by Lord Atkin in Donoghue v Stevenson. More prosaically, for Lord Reid "life would be impossible in modern conditions unless on the highway and in the market place we were entitled to rely on the other man behaving like a reasonable man" ${ }^{13}$ These are general duties arising between strangers, between everyone. Lawyers today take this for granted, yet the contrast with the "heyday of classical contract theory, when nearly all liabilities were thought to depend on some element of free choice, or consent", is striking. ${ }^{14}$

\footnotetext{
${ }^{7}$ Precisely Tony Weir's criticism of Hedley Byrne v Heller [1964] A.C. 465: "Liability for syntax" [1963] C.L.J. 216, 218 ("One can hope, perhaps, that in most cases it will continue to be 'reasonable' to rely only on a word one has bought"). See further D. Campbell, "The curious incident of the dog that did bark in the night-time: What mischief does Hedley Byrne [...] correct?” in K. Barker, R. Grantham and W. Swain (eds.), The Many Faces of Misstatement Liability: 50 Years On From Hedley Byrne v Heller (Oxford 2015, forthcoming).

${ }^{8}$ P.S. Atiyah, The Rise and Fall of Freedom of Contract (Oxford 1979) (Rise and Fall) 501.

${ }^{9}$ P.S. Atiyah, Book review (1981) 95 Harvard L.R. 509, 520-521 (emphasis in original).

${ }^{10}$ Atiyah, Rise and Fall 502; (1842) 10 M. \& W. 109, [1932] A.C. 562.

${ }^{11}$ Atiyah ibid.

${ }^{12}$ Atiyah, "Medical malpractice" n. 000 above, 289 n.13 (emphasis in original).

${ }^{13}$ Gollins v Gollins [1964] A.C. 644, 664.

${ }^{14}$ Atiyah, Rise and Fall 501
} 
Far from the absence of contract excluding tort liability (through "respect for individual autonomy"), Markesinis argued (addressing unreformed privity of contract) that English law has "An expanding tort law-[as] the price of a rigid contract law". ${ }^{15}$ Atiyah also welcomed recourse to tort where the absence of contractual liability arises from "arbitrary and perhaps technical restrictions". ${ }^{16}$ The high water mark in pure economic loss liability came in 1982 with Junior Books $v$ Veichi. ${ }^{17}$ But within a decade the courts had accepted that recognising tort duties of care within large construction/engineering projects risked subverting the contractual structure. ${ }^{18}$ Even Atiyah agreed that cases involving "a deliberate refusal to accept responsibility in contract" should be treated differently. ${ }^{19}$ Subcontractors' and suppliers' roles are deliberately separated from main contractors'. "There simply is no point in this elaborate set of commercial arrangements if the various parties are all liable for negligence in tort anyhow". ${ }^{20}$ To avoid "free-riding", tort "should not duplicate opportunities of protection of the plaintiff and deterrence of the defendant which were already available to the plaintiff but which the plaintiff failed to take". ${ }^{21}$ Atiyah nevertheless observed that to accept this critique of Junior Books one must "follow the ideology of the New Right" with its "great revival of belief in Freedom of Contract". ${ }^{22}$ Fleming, too, argued that denying actions to those deemed capable of protecting themselves through contract reflected "the primacy of private ordering, expressing the ideology of the free-marketers of the $80 \mathrm{~s}$ ". ${ }^{23}$ Such arguments receive corroboration from the opposition of Judge Richard Posner to economic loss liability in tort. Posner J. prefers to describe it as "commercial loss" to make the point that:

tort law is a superfluous and inapt tool for resolving purely commercial disputes. We have a body of law designed for such disputes. It is called contract law. ${ }^{24}$

Thus, whether to impose tort liability in the absence of a contract is no dry, technical question. Even to ("merely") fill "gaps" assumes what "full" protection requires. If the parties could have contracted for the obligation, does tort liability not (at best) give the claimant something for nothing or (at worst) upset the parties' intentional exclusion of liability inter se? Such reasoning has now been accepted in some pure economic loss cases. ${ }^{25}$ It does assume the primacy of contractual arrangements, as Fleming and Atiyah point out. ${ }^{26}$ Arguably

\footnotetext{
${ }^{15}$ (1987) 103 L.Q.R. 354.

${ }^{16}$ P.S. Atiyah, "Freedom of Contract and the New Right" in Essays on Contract (Oxford 1988) (Essays), 380.

${ }^{17}[1983] 1$ A.C. 520.

${ }^{18}$ Simaan General Contracting Cov Pilkington Glass [1988] Q.B. 758.

${ }^{19}$ Essays 382 (emphasis in original)

${ }^{20}$ Atiyah ibid. Cf. p. 000 below.

${ }^{21}$ J. Stapleton, "Duty of care: peripheral parties and alternative opportunities for deterrence" (1995)

111 L.Q.R. 301, 302. Similarly, Campbell n.000 above.

${ }^{22}$ Essays 382, 385

${ }^{23}$ J.G. Fleming, "Tort in a Contractual Matrix" (1993) 5 Canterbury L.R. 269 at 277 (quoted by

Stapleton n 000 above at 345, denying that her argument "accords primacy to the contractual paradigm").

${ }_{24}$ Miller v US Steel Corpn. 902 F.2d 573 (1990). Cited in Perre v Apand Pty Ltd (1999) 164 A.L.R. 606, [121]-[122] per McHugh J. ("This passage contains an important truth").

${ }^{25}$ Campbell n.000 demands abolition of the "Hedley Byrne principle" itself (especially deploring Henderson $\checkmark$ Merrett Syndicates Ltd [1995] 2 A.C. 145).

${ }^{26}$ Campbell ibid accepts this, setting out his personal political belief in market ordering to underline the point (and tracing the contrasting intellectual climate for Hedley Byrne back to the contemporary triumph of "political authority ... as the final arbiter of economic life": C.A.R. Crosland, The Future of Socialism (London 1956), 73).
} 
today's "intellectual climate", like that of the early nineteenth century, subscribes to: "Free choice in all things, rational planning, calculated risk assessment, and the severest limitation of the active role of state and judge". ${ }^{27}$ But since Donoghue v Stevenson a very different approach has been taken to physical injury claims. Here it remains the case, conversely, that "the law of tort is the general law, out of which the parties can, if they wish, contract". ${ }^{28}$

The primacy of contract in the public sphere today, following the "outsourcing" or "contracting-out" of service provision, occasioned the claimant's legal difficulties in Woodland. Before that great policy shift of the 1980s (which remains politically controversial), ${ }^{29}$ the fateful swimming lesson would have taken place in a pool staffed by council-employed lifeguards for whose negligence the council would have been vicariously liable. ${ }^{30}$ The Supreme Court used that historical point to support liability for contractors; outsourcing should not worsen the legal position of injured members of the public (compared to the era when services were provided directly by council employees). ${ }^{31}$ This too, of course, is an ideological position. ${ }^{32}$ Previously the House of Lords accepted that outsourced care-home provision by a private company meant that the Human Rights Act 1998 did not apply (whereas the Act would, uncontroversially, have applied to a council-operated home). Lord Neuberger noted that part of the rationale for outsourcing "may be to avoid some of the legal constraints and disadvantages which apply to local authorities but not to private operators"; it was not for the court to rule on the validity of that policy, "unattractive though it may be to some people". ${ }^{33}$ Such abstentionism is no doubt a policy choice also. But at least Lord Neuberger acknowledged the sensitive dilemma. In Woodland the Supreme Court simply assumed that outsourcing should not worsen the claimant's position. That position is not indefensible, of course. It would be a stretch of the imagination to attribute to Parliament a positive intention of making injured public service users worse off by contracting-out. On the other hand, the economic structure of outsourcing, especially the insurance arrangements adopted, arguably do require authorities to be insulated from their contractors' negligence. ${ }^{34}$ But these arguments were simply not considered by the Supreme Court. $^{35}$

Contrary to the Supreme Court's expansionary approach, it is widely accepted that outside directly inflicted physical injury cases, certain obligations are owed only when paid for-i.e. in contract, but not in tort. Sometimes this is implicit, sometimes openly acknowledged ${ }^{36}$ and sometimes even the justification for the absence of liability in tort.

Emergency services generally owe no common law duty of care to reply to call-outs. ${ }^{37}$ The absence of liability for omissions applies even when the police are made aware of credible threats of severe personal injury, but fail to act. ${ }^{38}$ Yet nobody doubts that a contractual claim would lie in parallel circumstances. When a plutocrat employs a bodyguard there can be no

\footnotetext{
${ }^{27}$ P.S. Atiyah, "Contracts, promises, and the law of obligations" in Essays 40.

${ }^{28}$ Henderson n.000 above, 193 per Lord Goff.

${ }^{29}$ P. Butler, "Thatcher's outsourcing fantasy fails in reality" The Guardian 16 October 2012.

${ }^{30}$ Recognised in Woodland by Lord Sumption at [25] (4) and Baroness Hale at [40].

${ }^{31}$ But compare the absence of "non-delegable duty" when British military hospitals were closed and medical services transferred to local German hospitals: A (A Child) $v$ Ministry of Defence [2004] EWCA Civ 641; [2005] Q.B. 183.

${ }^{32}$ Consider YL v Birmingham City Council [2007] UKHL 27; [2008] A.C. 95; S. Palmer, "Public, private and the Human Rights Act 1998: An ideological divide” [2007] C.L.J. 559.

${ }^{33} Y L$ ibid [152].

${ }^{34}$ R. Merkin and J. Steele, Insurance and the Law of Obligations (Oxford 2013), 236, 245-247.

${ }^{35}$ Cf. [2012] EWCA Civ 239 [34], [38], per Tomlinson L.J.

${ }^{36}$ Robinson v PE Jones (Contractors) Ltd. [2011] EWCA Civ 9; [2012] Q.B. 44, [76], [79] per Jackson L.J.

${ }^{37}$ Capital \& Counties plc v Hampshire County Council [1997] Q.B. 1004 (fire brigade). Cf. Kent v Griffiths [2001] Q.B. 36 (ambulance).

${ }^{38}$ Van Colle v Chief Constable of Hertfordshire [2008] UKHL 50; [2009] 1 A.C. 225.
} 
doubt that the guard's contractual duties include responding to credible threats of violence against his employer. Or the resident of an exclusive gated community would be able to sue the firm employed to provide security services for negligently failing to apprehend burglars in her property; a claim denied to oi $\pi \mathrm{o} \lambda \lambda$ oí suing the police in tort. ${ }^{39}$ It would be ridiculous to posit contractual immunity here for failing to provide the service paid for, purely because public authorities are not liable in tort to the public at large for similar failings. ${ }^{40}$ Conversely, while the absence of emergency service liability has certainly been criticized, ${ }^{41}$ the objection is not that those who pay for similar services privately would have an action in contract and that the public (suing in tort) should not be worse off. The police themselves might be employed to provide "special services" for payment, ${ }^{42}$ and thus (presumably) owe more extensive duties in contract than to the public at large. Tort sets its baseline independently from potentially wider rights in contract (for which people can, if they will, pay).

Courts have regularly dismissed tort claims while expressly acknowledging that a similar claim in contract might have succeeded. An example is "loss of a chance", which has not been permitted to form the basis of claim in negligence. ${ }^{43}$ In one leading case Lord Scott suggested that claimants relying instead on contracts of employment might have been able to recover such losses. ${ }^{44}$ Assuming this suggestion well founded, ${ }^{45}$ the different result would follows from another doctrinal axiom: that while damage is the gist of the action in negligence (and so its existence must be proved on the balance of probabilities), a breach of contract is actionable per se (and consequential loss is quantified on a "chance" basis). This explains other divergences, including that over "preventive damages". ${ }^{46}$

Not all judges have approved such differential outcomes. In Hotson, Donaldson M.R. advocated loss-of-chance claims in tort, observing that if they were denied, National Health Service patients would be worse off than private patients relying on contracts in otherwise "identical circumstances". The Master of the Rolls was "quite unable to detect any rational basis for [such] a state of the law". ${ }^{47}$ But the House of Lords was, and has remained, unmoved. That paying patients can recover lost chance damages has not entailed recognition of that head of loss in negligence. ${ }^{48}$

McFarlane v Tayside Health Board settled the "wrongful birth" debate: the pursuers could not recover the cost of bringing up a child conceived after an allegedly negligent vasectomy.

\footnotetext{
${ }^{39}$ Alexandrou v Oxford [1993] 4 All E.R. 328.

${ }^{40}$ Compare C. McKay, "Concurrent liability in claims for loss of chance of a better medical outcome" (2012) 20 Torts L.J. 29 (arguing that if one cannot recover such damages in tort, the same should be true in contract. An exception is allowed for "express contractual guarantee[s] ... demonstrated through explicit and unequivocal representations", but would the protective obligation not be implicit, in the examples given in the text?).

${ }^{41}$ e.g. S. Tofaris and S. Steel, "Police Liability in Negligence for Failure to Prevent Crime: Time to Rethink” University of Cambridge Faculty of Law Research Paper No. 39/2014 (via SSRN).

${ }^{42}$ Police Act 1996, s.25(1).

${ }^{43}$ Gregg v Scott [2005] UKHL 2; [2005] 2 A.C. 176, Rothwell v Chemical \& Insulating Co [2007] UKHL 39; [2008] 1 A.C. 281, Hotson v East Berkshire A.H.A. [1987] A.C. 750.

${ }^{44}$ Rothwell ibid [74] (cf. A. Burrows, "Uncertainty about uncertainty: damages for loss of a chance" [2008] J.P.I.L. 31, 42).

${ }^{45}$ For criticism cf. McKay n.000 above.

${ }^{46}$ J.G. Fleming, "Preventive Damages" in N.J. Mullany (ed.), Torts in the Nineties (Sydney 1997); D.

Nolan, "Preventive Damages" (S.L.S. Conference paper, 2014).

${ }^{47}$ n.000 above p.760 (Court of Appeal). See similarly Gregg v Scott [2002] EWCA Civ 1471, [65] per

Mance L.J.

${ }^{48} \mathrm{Cf}$. McKay n.000 above (absence of liability in tort should entail the same in contract).
} 
The McFarlanes' action, against an NHS authority, was necessarily delictual. ${ }^{49}$ But it was accepted that the position of a private patient suing in contract could well be different. Lord Slynn of Hadley stated: "If a client wants to be able to recover such costs he or she must do so by an appropriate contract" ${ }^{0}$ This accepts (as it must) that people can, if they wish (and can find a willing doctor) bargain for protection against the costs of childcare should the operation fail. Freedom of contract. But that can scarcely require the same rights of action in tort to those who have not contracted for it. On the contrary, as Lord Slynn implies, tort protects certain basic rights (especially personal rather than economic interests) that people can pay to enhance by contracting for higher protection, if they are able.

It is hard to see how this could be otherwise. The law allows people wide freedom to contract for services, on whatever terms they choose, including the rights of action should things go wrong. Tort law would collapse if its internal structure were replaced by speculation about the liabilities that parties might have assumed by contract. For this reason, pace Lord Sumption, "the mere absence of consideration" does, quite properly, "lead to an entirely different result". ${ }^{51}$ It is true that this may also lead to indirect social discrimination. ${ }^{52}$ Those employing private bodyguards, or paying for private education, are necessarily persons of means. Those reliant on equivalent public services (the police, state schooling) may not be wealthy. To the extent that such contracts confer broader rights of action, the rich will be better protected against negligent harm. But you get what you pay for. The objection (if this is unfair) is not that the private consumer is protected too well, but that tort protects the public service recipient inadequately.

The Supreme Court's express disapproval of distinctions (in the present context) between state and private schooling or healthcare has undeniable egalitarian appeal. Such sentiments may or may not show the judiciary in tune with general social attitudes - the position is by no means uncontroversial. ${ }^{53}$ But egalitarianism can hardly efface all doctrinal differences between contract and tort. So long as tort provides a certain level of protection to everyone (irrespective of payment) according to its own established structure and doctrine, and so long as people are entitled to use their wealth to contract for higher levels of protection, such distinctions are unavoidable. Liability for the fault of an independent contractor is one well-settled distinction. It is not clear why courts should rush to blur it when in other areas (like loss of a chance), recipients of public services have been left worse off than private clients suing in contract. If anything should be criticised it is not the contract-tort distinction, but the absence of liability for independent contractors in tort per se.

\section{Duties to Ensure that Care is Taken (and the “Non-Delegable Duty”)}

A contractual "duty of care" is usually interpreted as one to see that care is taken (by whoever actually provides the relevant service). In tort, by contrast, a duty of care is normally just that - a duty that the defendant herself take reasonable care. Exceptionally, however, a more stringent tortious duty is imposed, that the defendant ensure that care is taken (by whoever is actually carrying out the relevant activity). This is known, very misleadingly, as a "nondelegable duty". No duty of care can be delegated, but its performance may well be (whether to employees, independent contractors, or otherwise). Sometimes the defendant would be

\footnotetext{
${ }^{49}$ See for discussion: Dow v Tayside University Hospitals NHS Trust 2006 S.C.L.R. 865; Holdich v Lothian

Health Board 2014 S.L.T. 495, [60]-[76].

${ }^{50}$ [2000] 2 A.C. 59, 76. Consider Thake v Maurice [1986] Q.B. 644.

${ }^{51}$ Woodland [25] (5).

${ }^{52}$ Cf. McKay n.000 above, 58: "undesirable and discriminatory social consequences" (but as seen,

McKay also accepts that people may contract for more extensive rights of action).

${ }^{53}$ Compare Sir K. Joseph and J. Sumption, Equality (London 1979).
} 
negligent not to "delegate" an activity to a more suitable third party (for example where expertise is needed). ${ }^{54}$ It would be absurd to create a doctrine to prevent such delegation. But the "non-delegable duty", despite its name, does no such thing. Engagement of independent contractors (and "delegation" of the relevant activity to them) remains perfectly permissible; however the defendant must exceptionaly ensure that they take reasonable care (or rather, since it is impossible to ensure that contractors are never careless, he must answer for any harm negligently caused).

It would be better to avoid the misnomer altogether. ${ }^{55}$ But the terminology is so well entrenched that it may be less confusing to continue calling "non-delegable duty" what is more accurately a duty to ensure that care is taken. The reformulation is not just playing with words. Taking the ordinary duty to be careful first, it is always permissible (and sometimes - as seeneven obligatory) to engage suitable persons to carry out an activity on one's behalf. The careful defendant must take reasonable steps to ensure that the persons engaged really are "suitable", and may thereafter need to instruct, train and supervise them, depending on the circumstances. But the most reputable, best instructed and closely supervised worker or firm may still make mistakes. Yet it is quite possible that one who employs a negligent worker has not been negligent himself. When owing the standard duty of care, the defendant employer will not be liable in that case.

To that statement two qualifications must be made: vicarious liability and the "nondelegable duty". The former is so important, and normal, that the qualification virtually swallows the rule. A defendant is vicariously liable for torts committed by his employees within the course of their employment. There are thus three ways to get judgment against the employer when a master-servant relationship exists. First to show that the servant was a tortfeasor and the tort in the course of employment. Secondly, to show "direct" negligence on the part of the employer, for example a failure to employ suitable staff or to train them properly; or thirdly (exceptionally) a "non-delegable duty", i.e. to ensure that care was taken by the employee. As Weir comments, all these situations are "inevitably triangular" but the "routes round the triangle really must be kept separate". ${ }^{56}$ Most claimants will take the first route, vicarious liability, for obvious reasons: the claimant does not have to prove the employer's fault (i.e. "direct" negligence), ${ }^{57}$ or the existence of an exceptional "non-delegable duty". But sometimes the simpler vicarious liability route is barred to the claimant. A tort might occur outside the course of employment. While that doctrine has been considerably expanded, ${ }^{58}$ cases will still arise where the servant-tortfeasor is on a "frolic of his own".

The extension of the course of employment, and other expansionary currents within vicarious liability, will divert ever more claims along this route. The paucity of claims resorting to "direct" negligence explains counsel's remarkable "round assertion" in 1986 that "no health authority ever had been, or in principle ever could be, under any such direct liability", with sufficient plausibility to raise doubts for Mustill L.J. ${ }^{59}$ It is now clear that a health authority may

\footnotetext{
${ }^{54}$ e.g. Haseldine v Dawe [1941] 2 K.B. 343; Farraj v King's Healthcare NHS Trust [2009] EWCA Civ 1203; [2010] 1 W.L.R. 2139, [103] per Sedley L.J.

${ }^{55}$ Cf. R. Stevens, "Non-delegable duties and vicarious liability” in J.W. Neyers et al. (eds.), Emerging Issues in Tort Law (Oxford 2007), 332 (“arguably a misnomer").

${ }^{56}$ J.A. Weir, A Casebook on Tort, $10^{\text {th }}$ ed. (London 2004), 292 (criticising Lister v Hesley Hall [2001] UKHL 22; [2002] 1 A.C. 215).

${ }^{57}$ Sometimes there may be no "direct" duty for reasons of public policy, but the defendant may nevertheless be vicariously liable for its employees' negligence: Phelps v Hillingdon L.B.C. [2001] 2 A.C. 619. Weir ibid 270 comments: "Given that the authorities cannot perform their functions at all except through individual social workers and teachers the circumvention of the principal rule ... seems clear.” ${ }^{58}$ Lister n. 000 above.

${ }^{59}$ Wilsher v Essex Area Health Authority [1987] Q.B. 730, 748 (cf. Browne-Wilkinson V.-C. at 778).
} 
indeed be directly liable for failing to provide adequate treatment. ${ }^{60}$ Direct institutional duties of care are often pleaded in cases where vicarious liability seems dubious. ${ }^{61}$ Its success naturally requires proof that the employer was at fault. ${ }^{62}$

One case in which vicarious liability remains axiomatically unavailable, despite its recent expansion, is when the person employed to do the job was an independent contractor. To affix liability on the negligent contractor's employer (more accurately, the contractor's customer), ${ }^{63}$ the claimant must show breach by the customer/employer of his own duty to the claimant. If that duty is the ordinary duty to be careful, the claim will fail unless the customer/employer was at fault in engaging the contractor. ${ }^{64}$ Of course many claims will founder on this requirement. Exceptionally however, the claimant has a much more advantageous route to the customer/employer - the "non-delegable duty". Because this is (recall) a duty to ensure that care is taken, the customer/employer is in breach of it (irrespective of fault on his part) whenever the contractor is negligent. It is a duty to ensure a certain result, not merely to take care: a form of strict liability. This constitutes the "non-delegable duty's" exceptional status: "it departs from the basic principles of liability in negligence by substituting for the duty to take reasonable care a more stringent duty, a duty to ensure that reasonable care is taken". ${ }^{65}$

Given this strict liability for the fault of another, the "non-delegable duty" bears more than a passing resemblance to vicarious liability. It has accordingly been dismissed as a "logical fraud" namely vicarious liability for the torts of independent contractors. Now from a strictly doctrinal point of view, this charge is baseless. It stands to reason that the "non-delegable duty" must operate differently from vicarious liability, or it could not be applicable to independent contractors (to be less mealy-mouthed, it could not outflank the prohibition on vicarious liability unless it were something other than vicarious liability). They are "two routes round the triangle"; in Baroness Hale's words, "conceptually quite different". ${ }^{67}$ The doctrinal apparatus certainly differs - the "course of employment" is not as such relevant in cases of independent contractors, although a not dissimilar exception for "casual or collateral negligence" has been recognised. ${ }^{68}$ Yet "non-delegable duties" are pled by tort claimants precisely because, and only because, there is no vicarious liability for independent contractors and the defendant may not have been careless personally. Despite the conceptual differences, the outcome is usually identical to vicarious liability.

This explains the appeal of "non-delegable duties" to claimants. Increasingly, judges have candidly admitted that "non-delegable duties" are recognised precisely to fill some perceived gap in vicarious liability. One such gap was the doctrine of "common employment": an exception to vicarious liability when one servant was injured by another of the same master. ${ }^{69}$ Judicial attitudes towards workplace injuries claims had softened by the end of the $19^{\text {th }}$ Century, as shown by the narrowed defence of volenti non fit injuria. ${ }^{70}$ Yet it was beyond

\footnotetext{
${ }^{60}$ Robertson v Nottingham H.A. (1997) 8 Med. L.R. 1, 13, per Brooke L.J.

${ }^{61}$ E.g. Lister n 000 above; Hudson v Ridge Manufacturing Co. [1957] 2 Q.B. 348; Attorney General of the British Virgin Islands v Hartwell [2004] UKPC 12; [2004] 1 W.L.R. 1273.

${ }^{62}$ Failed at trial in Lister but succeeded in Hudson and Hartwell (all ibid).

${ }^{63}$ Weir n. 000 above, p. 315.

${ }^{64}$ e.g. Occupiers' Liability Act 1957, s. 2(4)(b).

${ }^{65}$ Kondis v State Transport Authority (1984) 55 A.L.R. 225, 234 per Mason J.

${ }^{66}$ G. Williams, "Liability for independent contractors" [1956] C.L.J. 180, 193.

${ }^{67}$ Woodland at [33].

${ }^{68}$ Penny v Wimbledon Urban District Council [1899] 2 Q.B. 72.

${ }^{69}$ Priestly v Fowler (1837) 3 M. \& W. 1.

${ }^{70}$ Smith $v$ Charles Baker \& Sons [1891] A.C. 325.
} 
the judges to remove the common employment defence. ${ }^{71}$ Instead, a "non-delegable duty" was created by the House of Lords in Wilsons \& Clyde Coal Co v English: ${ }^{72}$ when one worker carelessly injured a fellow worker, the employer was put in breach of its own duty to ensure that care was taken (i.e. to provide a safe system of work). Yet despite being the "leading example" of the "non-delegable duty" approach, "Lord Wright's approach [in Wilsons] is vulnerable to the criticism that he advances no reason or policy consideration for fixing the employer with the higher duty to see that care is taken instead of the duty that he himself take reasonable care". ${ }^{73}$ Courts now accept what was once seen as a dangerously Realist answer: the policy in Wilsons was to fill the gap in vicarious liability created by common employment. ${ }^{74}$

Similarly, in a period when there were real doubts over whether hospital surgeons could be classified as employees (given that close control was the traditional hallmark of "servant" status), Lord Greene M.R. and Denning L.J. suggested that hospitals owed a "nondelegable duty" to ensure that all staff, irrespective of employment status, took reasonable care. ${ }^{75}$ As Baroness Hale stated in Woodland, this invocation of the "non-delegable duty", too, was "to get round what was then perceived to be another problem with the law of vicarious liability". ${ }^{76}$ Her Ladyship approved the circumvention, suggesting it as a "ready answer" to another lacuna that she identified in the context of modern hospitals (and schools) - injuries caused by the carelessness of an agency nurse or supply teacher. ${ }^{77}$

Such judicial frankness is both welcome and rare. But it does raise further questions. What are the criteria for recognising an exceptionally stringent tortious duty to ensure that care is taken, departing as it does from the basic obligation in negligence to take reasonable care? If the sole criterion is to plug gaps in vicarious liability, this simply begs the question. Stating that there is a "gap" to be filled assumes that vicarious liability is (in the relevant respect) too narrow, but that needs to be demonstrated. And if vicarious liability is too narrow, it does little credit to leave that doctrine unreformed while producing a simulacrum of outcome via the "non-delegable duty". Should vicarious liability be flawed it demands reform, not a conceptual tap-dance to avoid the issue. Beatson L.J. has recently observed that although for critics of vicarious liability "the concept of a non-delegable duty may appear to be a more attractive, direct and principled solution", in fact (in Paula Gilliker's words) resort to it "derives from frustration at the limits of vicarious liability rather than any considered conceptual development". ${ }^{78}$ His Lordship therefore proceeded to address the boundaries of vicarious liability, as raised by the case. Such direct engagement is most welcome. Other recent cases have extended vicarious liability from its paradigm of the master-servant relationship. ${ }^{79}$ The

\footnotetext{
${ }^{71}$ Eventually abolished by statute: Law Reform (Personal Injuries) Act 1948, s.1.

${ }^{72}$ [1938] A.C. 57.

${ }^{73}$ Kondis n 000 above 231.

${ }^{74}$ E.g. Farraj n.000 above, at [74] per Dyson L.J.; Woodland at [36] per Baroness Hale. Both learned judges note that the Wilsons doctrine persists although its raison d'être disappeared with the abolition of common employment in 1948. They seem unperturbed by this. But cf. Sedley L.J. in Farraj at [103] ("caution is needed in importing the palliative concept of the non-delegable duty into other legal relationships”); O.W. Holmes, “The Path of the Law” (1897) 10 Harvard L.R. 457, 469.

${ }^{75}$ Gold v Essex County Council [1942] 2 K.B. 293, 301 and Cassidy $v$ Ministry of Health [1951] 2 K.B. 343, 362-363 (respectively).

${ }^{76}$ Woodland at [37].

${ }^{77}$ Ibid.

${ }^{78}$ Cox v Ministry of Justice [2014] EWCA Civ 132; [2014] I.C.R. 713, [61] (citing P. Gilliker, Vicarious Liability in Tort: A Comparative Perspective (Cambridge 2010), 144).

${ }^{79}$ E v English Province of Our Lady of Charity [2012] EWCA Civ 938; [2013] Q.B. 722; Various Claimants V Catholic Child Welfare Society [2012] UKSC 56; [2013] 2 A.C. 1. See P. Morgan, "Recasting Vicarious Liability” [2012] C.L.J. 615.
} 
extension has not yet reached contractors. If and when that nettle is grasped, what independent reason for the retention of "non-delegable duties" in tort could be cited?

The strong suspicion remains that tort law exceptionally imposes strict liability to ensure that care is taken to reach functionally identical results to vicarious liability in situations where that doctrine is held inapplicable. Admittedly, by conceptually distinct means. But which route we take round the triangle has little importance beyond preserving the doctrinal decencies (or less charitably, allowing questions about vicarious liability to remain unasked). In contract law there is little debate about which route to take. Liability for others' negligence poses no special difficulties when promisors are strictly liable for non-performance.

\section{CONTRACTUAL LiabiLiTy FOR THE FAULT OF OTHERS}

The characteristic strictness of liability for breach of contract is not always sufficiently appreciated. ${ }^{80}$ Strikingly, even duties that appear at first sight to be duties "of care" are interpreted as duties to ensure that care is taken - a strict duty to achieve a particular result, not merely take reasonable steps to achieve it.

Just as "why" a promisor failed to perform is generally "immaterial", so is the question of "who" was responsible for the failure. Lord Diplock explained in Photo Production v Securicor that promisors frequently, and often of necessity, engage others to perform what they have undertaken to do:

My Lords, it is characteristic of commercial contracts, nearly all of which today are entered into not by natural legal persons, but by fictitious ones, i.e., companies, that the parties promise to one another that some thing will be done; for instance, that property and possession of goods will be transferred, that goods will be carried by ship from one port to another, that a building will be constructed in accordance with agreed plans, that services of a particular kind will be provided. ... Where what is promised will be done involves the doing of a physical act, performance of the promise necessitates procuring a natural person to do it; but the legal relationship between the promisor and the natural person by whom the act is done, whether it is that of master and servant, or principal and agent, or of parties to an independent subcontract, is generally irrelevant. If that person fails to do it in the manner in which the promisor has promised to procure it to be done, as, for instance, with reasonable skill and care, the promisor has failed to fulfil his own primary obligation. ${ }^{82}$

Cockburn C.J. similarly noted that promisees are usually "indifferent ... whether [performance] is done by the immediate party to the contract, or by someone on his behalf". ${ }^{83}$ The promisee expects a service of the stipulated quality to be provided — not that the promisor personally performs it to that quality, or indeed personally does anything at all.

Here is the answer to Weir's question, "Why do textbooks on Contract not have a chapter on vicarious liability?" ${ }^{44}$ A company selling goods CIF Rotterdam is not promising that it will deliver them there itself, let alone that it will personally take reasonable care to do it. Nor does the buyer expect these things. The promise is construed in absolute terms: the seller

\footnotetext{
${ }^{80}$ See G.H. Treitel, "Fault in the common law of contract" in M. Bos and I. Brownlie (eds.), Liber Amicorum for Lord Wilberforce (Oxford 1987); O. Ben Shahar and A. Porat (eds.), Fault in American Contract Law (Cambridge 2010).

${ }^{81}$ Raineri $v$ Miles [1981] A.C. 1050, 1086 per Lord Edmund-Davies.

${ }^{82}$ Photo Production Ltd. v Securicor Transport Ltd. [1980] A.C. 827, 848 (cited in Woodland at [7]).

${ }^{83}$ British Wagon Co v Lea \& Co (1880) 5 Q.B.D. 149, 153-154.

${ }^{84}$ Weir n.000 above 307.
} 
will ensure that the goods are delivered on the specified date and if they are not he will in breach of his own contractual undertaking, irrespective of whether he could have done otherwise. Whether the default is attributable to the promisor personally (impossible when the promisor is not a natural person), or to his own employees, or to an independent contractor is immaterial. Strict liability makes such questions of fault (and, a fortiori, whose fault) irrelevant.

Although not quite so obviously, contractual duties that appear to be framed in lessthan-absolute terms are equally stringent. A duty to supply goods of satisfactory quality is not a duty to supply perfect goods guaranteed against any risk of failure. The duty in a charterparty to supply a seaworthy ship does not require an unsinkable vessel. Nevertheless, there is an absolute duty to achieve the relevant (qualified) standard: it is no defence for a seller to prove that he took all possible care to deliver satisfactory goods (if those delivered did not, in fact, reach that standard), or for the shipowner to plead that he did everything possible to make the ship seaworthy (if, in fact, it was not).

Crucially for present purposes, even contractual duties to render services of a good, professional standard are construed as a duty to ensure that care is taken. ${ }^{85}$ For example, in construction contracts the builder's usual obligation is to build in a "workmanlike manner". ${ }^{86}$ But this imports a guarantee that the work is done in a "workmanlike" way, whoever actually carries it out. Builders commonly engage various subcontractors (in addition to their own workforce); even the largest firms contract-out specialist tasks like installing lifts. Should any of the subcontractors (or their sub-subcontractors, etc) fail to do the work in a "workmanlike manner", the main building contractor will be put in breach of its own duty to see that the project is satisfactorily carried out and completed. ${ }^{87}$ It is immaterial that a reputable subcontractor had been selected, instructed and monitored. A duty to guarantee that care is taken by whoever does the work, although exceptional in tort, is a standard feature of construction contracts.

Generations of common lawyers have reasoned that when someone pays for goods of a particular quality, or for a service of a certain standard, an absolute obligation presumptively arises to provide it - not merely an obligation to make reasonable efforts to provide it. The customer is purchasing the stipulated goods or services, and it is a matter of complete indifference to him how the provider chooses to render them. (For the reasons given by Lord Diplock, it is (to put it no higher) readily foreseeable that the provider will rely on various employees, agents and contractors to do so.) Strict duties therefore meet commercial expectations.

Strong evidence for that assertion is the widespread acceptance of the common law position in industry-adopted standards (which could, of course, replace the default strict liability with fault-based standards if these were commercially preferable) ${ }^{88}$ For example, major construction projects are usually governed by Joint Contracts Tribunal standard forms, drawn up by representatives of all the industry's interest groups. The JCT forms make no attempt to displace the builder's strict duty to ensure that the project is completed in a "workmanlike manner" by a personal obligation to take reasonable care that could be discharged by employing competent subcontractors. Understandably so. Such a limited duty would be

\footnotetext{
${ }^{85}$ E.g. Supply of Goods and Services Act 1982, s.13: "In a contract for the supply of a service where the supplier is acting in the course of a business, there is an implied term that the supplier will carry out the service with reasonable care and skill.”

${ }^{86}$ Implied at common law (GH Myers v Brent Cross Service Co [1934] 1 K.B. 46) and express in the JCT standard forms (section 2.1, "The Contractor shall carry out and complete the Works in a proper and workmanlike manner...").

${ }^{87}$ E.g. Rumbelows $v$ AMK (1982) 19 B.L.R. 25.

${ }^{88}$ R.E. Scott, "In (partial) defence of strict liability in contract" in Ben-Shahar and Porat n.000 above.
} 
much less valuable to the employer. He would pay much less for it, if he would accept it at all — which he probably would not.

Chains of contracts in the building industry (from employer, to main contractor, to subcontractor...) remain governed by privity of contract. Even since the common law doctrine was relaxed by statute, nearly all JCT forms have been careful to exclude the possible operation of the Contracts (Rights of Third Parties) Act 1999. Each party answers in law only to his immediate employer, and not to other parties further up the chain (even though they too will foreseeably suffer loss from his shoddy work). Such an arrangement assumes and necessitates the strict liability discussed above. Imagine that a subcontractor, C, does unsatisfactory work despite being carefully engaged and supervised by the main contractor, B. Given privity of contract, the building owner (i.e. B's employer, A) will not be able to sue $\mathrm{C}$ in contract for the substandard work - and after a brief period of confusion this remains the position in tort also. ${ }^{89}$ Were (blameless) B not liable to A for C's substandard work either, then A would have no remedy against anyone - a commercial absurdity. (Hence, no doubt, why leading works on construction law do not expressly discuss B's contractual liability in this common situation: it truly goes without saying.) But the result is not felt unduly harsh on B, who can pass liability on to the "ultimate culprit" using the "well known chain of third party procedures".

This approach is not of course limited to building contracts. A rare case in which the principles were openly considered is Wan ${ }$ Kwan Kin Travel Services. ${ }^{91}$ The plaintiff was drowned owing to the negligence of a transportation company in China during a holiday booked with the first defendant, a Hong Kong based travel agent. The issue was whether the travel agent "undertook no more than that [to] arrange for services to be provided by others", or undertook to provide those services itself. The distinction appears slender. However, in the first case the duty can be discharged by showing that reasonable care and skill was taken in selecting those other persons, whereas in the second case:

The fact that the supplier of services may under the contract arrange for some or all of them to be performed by others does not absolve the supplier from his contractual obligation. He may be liable if the service is performed without the exercise of due care and skill on the part of the subcontractor... The obligation undertaken is thus, if the person undertaking to supply the services performs them himself, that he will do so with reasonable skill and care, and that if, where the contract permits him to do so, he arranges for others to supply the services, that they will be supplied with reasonable skill and care. ${ }^{92}$

The Privy Council held that the travel agent through its contract "undertook to provide and not merely to arrange all the services" and was therefore liable for the negligence of its Chinese subcontractor. Their Lordships disagreed with the Hong Kong Court of Appeal's view that it was "an intolerable burden ... to be held liable for the negligence of a transport operator in another country". ${ }^{93}$ Lord Slynn observed that the travel agent could protect itself by bargaining for contractual protection from those who were to perform the services (the "chain of contracts" reasoning described above), or by including a suitable exemption clause in contracts with its customers. ${ }^{94}$

\footnotetext{
${ }^{89}$ Simaan n.000 above (cf. Junior Books n.000 above).

${ }^{90}$ Young \& Marten Ltd. v McManus Childs Ltd. [1969] 1 A.C. 454, 475 per Lord Upjohn. See e.g. Greenwich Millennium Village Ltd. v Essex Services Group plc [2014] EWCA Civ 960; [2014] 1 W.L.R. 3517.

${ }^{91}$ [1996] 1 W.L.R. 38.

${ }^{92}$ Ibid p.42.

${ }^{93}$ Quoted ibid p.41.

${ }^{94}$ Ibid pp.46-47.
} 
To sum up, it is standard practice to construe contractual duties "of care" as an obligation to ensure that care is taken when the relevant service is rendered. (Of course when the obligation is personal to the promisee - e.g. a celebrated singer engaged to sing at a concert - it amounts to a personal duty of care, but such situations are uncommon in commercial law for the reasons given by Lord Diplock. ${ }^{95}$ ) The Supreme Court in Woodland was therefore right to assume that a client suing a private school or hospital in contract would succeed where harm was caused by a negligent contractor (e.g. agency nurse or supply teacher). ${ }^{96}$ There is strong reason to believe that the strictness of this approach meets commercial expectations. Moreover, strict liability for subcontractors accords with the default strictness of liability across the law of contract. There is no need to talk about a special category of "non-delegable duty" (nor indeed, as Weir observes, "vicarious liability") in a general system of strict liability. The promisor is put in breach of his own (absolute) duty to render the promised services by the actual performer's failure. Contractual obligation is concerned with what has to be done- how it is done (and by whom it is done) is usually immaterial.

It might be thought immoral to hold people liable for failing to achieve that which they could not reasonably do - such as ensuring that a remote independent company take care of your customers, in Wan. Moral concerns have apparently encouraged retention of a fault standard in German contract law. ${ }^{97}$ If so, the common law is amoral with insouciance. A contractual promise is treated as a guarantee of performance or, at least, its monetary equivalent. The doctrine of frustration is accordingly narrow. The fact that it is impossible to deliver goods for reasons entirely beyond the seller's control does not excuse him. ${ }^{98}$ No more does the impossibility of control by the travel agent in Wan. Contract lawyers devote very little attention to the questions of fault "with which tort lawyers are so familiar". ${ }^{99}$ The two systems have entirely different assumptions about moral responsibility and fault.

\section{V. "VOLUNTARY ASSUMPTION OF RESPONSIBILITY” IN TORT}

The previous section shows that duties to ensure that care is taken are standard in the law of contract, consistent with strict contractual liability and satisfying commercial expectations. By contrast fault plays a dominant role in tort. Even fully accepting that significant pockets of strict liability remain and "the common law's approach to fault is explicably more diverse than is sometimes realised", ${ }^{100}$ fault is frequently necessary. By definition liability in the tort of negligence requires it. One can lament the "one-size-fits-all approach to fault", ${ }^{101}$ and decry negligence's "staggering march", ${ }^{102}$ but a "non-delegable duty of care" remains a contradiction in terms. It is not a duty to be careful at all, but one to ensure a particular result (i.e. that the activity in question is carefully carried out). If tort liability generally requires fault then a good reason is needed to depart from that standard by imposing a strict duty to ensure that care is taken.

\footnotetext{
${ }^{95}$ Cf. British Waggon v Lea n.000 above (distinguishing Robson v Drummond (1831) 2 B. \& Ad. 303).

${ }^{96}$ Cf. I. Kennedy and A. Grubb, Medical Law: Text with Materials, $2^{\text {nd }}$ ed. (London 1994) 414-415.

${ }^{97}$ S. Grundmann, "The fault principle as a chameleon of contract law: A market function approach" in Ben-Shahar and Porat n.000 above.

${ }^{98}$ E.g. Blackburn Bobbin Co. v T.W. Allen \& Sons [1918] 2 K.B. 467; The Mary Nour [2008] EWCA Civ 856; [2008] 2 Lloyd's Rep. 526.

${ }^{99}$ Treitel, n.000 above, p. 185.

${ }^{100}$ Stevens, n.000 above, p. 368 .

${ }^{101}$ Ibid

${ }^{102}$ J.A. Weir, "The staggering march of negligence" in P.F. Cane and J. Stapleton (eds.), The Law of Obligations: Essays in Celebration of John Fleming (Oxford 1998).
} 
Even Robert Stevens, who identifies the "swollen 'tort' of negligence" (rather than the "non-delegable duty") as "the cuckoo in the nest" of tort law, ${ }^{103}$ accepts that strict liability's limits necessitate limits on "non-delegable duties". It has been impossible to identify a general principle of strict liability for dangerous things since Read $v$ J Lyons \& Co. ${ }^{104}$ It accordingly became anomalous to preserve "non-delegable duties" for so-called ultra-hazardous activities. ${ }^{105}$ Stevens admits the inconsistency. "It seems insupportable that a [careful] defendant will be held liable for the extra-hazardous activity of an independent contractor, when it would not be so liable if it carefully carried out the same activity itself." ${ }^{106}$ But does this reasoning not apply to any area in which liability is usually based on fault (which is much of the law of torts)? Stevens rightly draws attention to strict liability under various statutes. ${ }^{107}$ But these are no more than further isolated instances of the "exceptional and heterogeneous" situations in which "a person may be liable although his own organisation has operated flawlessly". ${ }^{108}$ Parliament might theoretically lay down general strict liabilities (e.g. for hazardous activities). But in this area as so often the legislature has seemed "afraid to rise to the dignity of a general proposition". ${ }^{109}$ The extant strict(er) statutory duties are piecemeal. No general strict duty (even less "nondelegable duty") can be synthesised from them. By contrast with the position in contract law, there is no general principle of strict liability, nor therefore strict liability for independent contractors, in tort.

It follows that there can be no general parallel between the undoubted contractual liability for an independent contractor's default and liability in tort. However in Woodland, Lord Sumption's analogy was drawn not in the archetypical tort situation between complete strangers but given a pre-existing relationship between the parties. Moreover, his Lordship considered cases where the defendant "assumes responsibility" to the claimant for the carefulness of his contractors. The analogy between contract and tort here seems strong. ${ }^{110}$ Commentators have argued persuasively that "assumption of responsibility" is the central principled determinant of the "non-delegable duty". ${ }^{111}$ The Supreme Court has now endorsed this explanation. It seems reassuring to have a unified theory in place of the ad hoc precedents that so "perplexed" Glanville Williams and had become little clearer half a century later. ${ }^{112}$ But on closer examination the explanation is much less convincing. Usually, liability has not been "assumed" but imposed by the courts. In its original nursery of pure economic loss that criticism has been widely accepted, so the elevation of "assumption of responsibility" into the touchstone for "non-delegable duties" is puzzling. For if liability depends more on judicial imposition than party intention, the analysis is simply pushed back one stage: when should such duties be imposed? Bluntly, "assumption of responsibility" provides no test at all, and no answers - it simply poses the same questions in a disguised form.

"Assumption of responsibility" has enjoyed mercurial favour from those set on extending tort liability in a contractual direction. Admittedly, when taken at face value its central case presents a seductive argument for liability. If a defendant expressly guarantees the

\footnotetext{
${ }^{103}$ n. 000 above, p.368.

${ }^{104}$ [1947] A.C. 156.

105 e.g. Honeywill v Larkin [1934] 1 K.B. 191.

${ }^{106}$ Stevens n.000 above 344.

${ }^{107}$ e.g. Nuclear Installations Act 1965 (near-absolute liability); Highways Act 1980, s. 58(2) (duty to ensure that care is taken).

${ }^{108}$ Weir (Casebook), n. 000 above, p. 270.

${ }^{109}$ F.W. Maitland, The Constitutional History of England (Cambridge 1908), 383.

${ }^{110} \mathrm{Cf}$. Atiyah n.000 above.

${ }^{111}$ Stevens n.000 above and J. Murphy, "Juridical foundations of common law non-delegable duties", both in J.W. Neyers et al. (eds.), Emerging Issues in Tort Law (Oxford 2007).

${ }^{112}$ A v MoD n.000 above, at [29] per Lord Phillips M.R. (referring to Williams n.000 above).
} 
carefulness of his contractors (or expressly undertakes to use reasonable care to protect the claimant's financial or other interests), there is a case for holding the defendant liable for not doing so even in the absence of payment (i.e. of contract). ${ }^{113}$ If the defendant's undertaking truly gives rise to a "relationship equivalent to contract" (without actually constituting one), ${ }^{114}$ that seems a good reason to allow recovery in negligence for kinds of loss, or in kinds of situations, that contract recognises (but tort normally does not). ${ }^{115}$ Such an undertaking may generate a positive duty to improve the claimant's position (whereas ordinarily "pure omissions" do not lead to liability in tort). An express undertaking to prevent self-harm generated an extraordinary duty of care of this kind in Calvert v William Hill. ${ }^{116}$ As Stevens says, where a duty is voluntarily assumed "the law is, inevitably, less concerned with preserving [the defendant's] interest in liberty of action". ${ }^{117}$ Such an assumption may override other rules that would ordinarily preclude liability, including the policy of protecting public authorities from claims that might engender a "defensive" approach. ${ }^{118}$

The great difficulty is how rarely the persuasive central case arises in practice. ${ }^{119}$ Not surprisingly, for how many people would willingly and expressly undertake wider legal liabilities without payment for doing so, or without compulsion $?^{120}$ The conjecture is born out by the case-law on pure economic loss. In very few cases involving liability for "assuming responsibility" did the defendant expressly undertake a legally enforceable obligation (one sounding liability in the event of careless performance). In the cognate area of promissory estoppel, some exhibit a sceptical attitude to such "undertakings"-Longmore L.J. has demanded clear evidence of an alleged promise to forgo rights without any obvious reciprocal benefit. $^{121}$

By contrast, in cases where "assumption of responsibility" has been invoked to hold defendants liable for (e.g.) pure economic loss in tort, judges have seemed enthusiastic to saddle defendants with exceptional tort liability when they could have- but did notcontractually promise to protect the relevant interests. ${ }^{122}$ Increasingly it has been accepted that "notional" or "objective" "assumption of responsibility" reflects judicial imposition rather than the intentions of the actual defendant. ${ }^{123}$ In which case it depends on questions of "fairness and policy" and is not "a simple question of fact". ${ }^{124}$ Thus "assumption of responsibility" usually

\footnotetext{
${ }^{113}$ But contrast Campbell, and Weir, n.000 above.

${ }^{114}$ Hedley Byrne \& Co. $v$ Heller \& Partners [1964] A.C. 465, 530 per Lord Devlin.

${ }^{115}$ E.g. S. Steel, "Rationalising Loss of a Chance in Tort" in E. Chamberlain et al. (eds.), Tort Law: Challenging Orthodoxy (Oxford 2013), 258; J. Edelman "Loss of a chance” (2013) 21 Torts L.J. 1, 7-9.

${ }^{116}$ [2008] EWHC 454 (Ch) (affirmed [2008] EWCA Civ 1427). See also e.g. Welsh $v$ Chief Constable of Merseyside [1993] 1 All E.R. 692.

${ }^{117}$ Stevens, n.000 above, p. 354.

${ }^{118}$ Elguzouli-Daf v Metropolitan Police Commissioner [1995] Q.B. 335, 348-350 per Steyn L.J. (discussing Welsh n.000 above); Gorringe v Calderdale M.B.C. [2004] UKHL 15; [2004] 1 W.L.R. 1057, [38]-[40] per Lord Hoffmann.

${ }^{119}$ K. Barker, "Unreliable assumptions in the modern law of negligence" (1993) 109 L.Q.R. 461 (although cf. n.000 above).

${ }^{120}$ Calvert n.000 above seems to provide a rare example (although N.B. bookmakers had chosen to demonstrate their social responsibility in the shadow of imminent government regulation of "problem gambling" under the Gambling Act 2005).

${ }^{121}$ Collier v P \& MJ Wright (Holdings) Ltd. [2007] EWCA Civ 1329; [2008] 1 W.L.R. 643, [45], [48]. See similarly Campbell n.000 above: agreeing to indemnify those who rely on one's words "could [be done] gratuitously, but [only] by the clearest words and would best be done backed by nominal consideration”.

${ }^{122}$ Cf. Stapleton, n.000 above.

${ }^{123}$ Customs v Barclays, n.000 above, at [5] per Lord Bingham.

${ }^{124}$ Ibid at [36] per Lord Hoffmann.
} 
operates as a mere cipher. It is expressive of the conclusion reached, not an independent reason for it.

Lord Sumption referred in passing to "assumption of responsibility's" usual relevance as a "tool" for controlling economic loss liability. ${ }^{125}$ But no mention was made of the many difficulties with it, and criticisms of it, in that context. This is unfortunate. Even one of the theory's prominent supporters, John Murphy, accepts that the language is:

apt to mislead ... insofar as it suggests an element of voluntariness on the part of the defendant which is clearly absent in most non-delegable duty cases ... The truth is that 'assumed responsibilities' in non-delegable duty cases are more commonly imputed by the courts than voluntarily undertaken by defendants. ${ }^{126}$

The oxymoronic enterprise of "calling an imposition an assumption" has been heavily criticised elsewhere. ${ }^{127}$ The real question is when such liability should be imposed. Search for a fictitious promise to undertake additional liability is very unlikely to provide the answer.

The landmark decisions expanding hospitals' direct liability over the last century generally identified relevant "undertakings" by the hospital. But no promissory conduct or statements by doctors or hospital managers have been identified. In Hillyer v St Bartholomew's Hospital (1909) "The only duty undertaken by the defendants is to use due care and skill in selecting their medical staff". ${ }^{128}$ Disapproving this in Gold v Essex County Council Lord Greene M.R. considered the obligations assumed by the hospital (whether contractual or otherwise). ${ }^{129}$ In Cassidy v Ministry of Health Denning L.J. founded his decision (a cornerstone of hospitals' "non-delegable duty") on the "acceptance" of a patient for treatment. By accepting him the hospital had undertaken to use reasonable care and skill. ${ }^{130}$ It is now well established that such acceptance generates a positive duty to treat (so that hospitals do not benefit from the "omissions principle"). ${ }^{131}$ Why this does not apply to (other) emergency services when they answer a 999 call is not wholly clear. ${ }^{132}$

But whether an NHS hospital could lawfully refuse to treat a patient is doubtful - in which case the voluntariness of their acceptance seems fictitious. ${ }^{133}$ Perhaps health authorities choose to open a hospital in a particular place, and individual doctors choose to practise medicine (or work at a given hospital or in a certain medical field). By this time however, the notion of "voluntary assumption" has become greatly attenuated, compatibly with Atiyah's very wide, and weak, version. Having considered implied terms in contracts of sale, Atiyah argued that the (clearly tortious) obligations on drivers were no less "voluntary". A driver "is

\footnotetext{
${ }^{125}$ Woodland at [11].

${ }^{126}$ Murphy n 000 above 384. Cf. Woodland at [23] per Lord Sumption: criteria for "non-delegable duty" include "an antecedent relationship between the claimant and the defendant ... (ii) from which it is possible to impute to the defendant the assumption of a positive duty to protect the claimant from harm" (emphasis added).

${ }^{127}$ Campbell n.000 above (invoking not just Lewis Carroll's Humpty Dumpty but Orwell's Big Brother: "Newspeak").

${ }^{128}$ [1909] 2 K.B. 820, 826 per Farwell L.J.

${ }^{129}$ [1942] 2 K.B. 293, 301-303.

${ }^{130}$ [1951] 2 K.B. 343, 360.

${ }^{131}$ Barnett $v$ Chelsea Hospital [1969] 1 Q.B. 428. (Is an ambulance a mobile hospital? Cf. Kent v Griffiths n.000 above.)

${ }^{132}$ Cf. n.000 above; D. Nolan, "The liability of public authorities for failing to confer benefits" (2011) 127 L.Q.R. 260, 280-281 (arguing that an ambulance assumes responsibility to the individual claimant, whereas the fire brigade acts for the benefit of the public at large).

${ }^{133}$ Cf. Holdich n.000 above at [63]-[65] (statutory regime inimical to argument that NHS authority contracted to supply treatment).
} 
voluntarily on the road, voluntarily driving his car, and may be said to submit himself to the requirements of the law with as much or as little truth as the seller of goods". ${ }^{134}$ Few would attempt to base road users' obligations to take care on assumption of responsibility. Such duties are acknowledged to be imposed by law. That is equally true of medical negligence.

Its expansion over the century since Hillyer's case has nothing to do with hospital authorities' moves to assume more extensive legally-enforceable duties. Rather, as one of the leading Canadian cases recognises, the tortious "relationship between hospitals and the public in contemporary society" has altered to reflect "profound changes in social structures and public attitudes relating to medical services and the concomitant changes in the function of hospitals in providing them". ${ }^{135}$ Kirby P. advocated the expansion of "non-delegable duties" to accommodate "the intensely technological nature of modern hospitals" - especially the use of "visiting experts" (who are not hospital employees) to operate equipment. ${ }^{136}$ The emphasis throughout has been on adapting liability to meet public expectations. It has surely been imposed by law, not voluntarily assumed by hospitals.

Woodland is another dubious example of "voluntarily assumed" responsibility. ${ }^{137}$ Previously, in Customs v Barclays Bank, a claim failed because the defendant bank's compulsion (by court order) to freeze its customer's account was inimical to the argument that it had voluntarily assumed responsibility to the claimant beneficiary of the freezing order (i.e. its customer's creditor). ${ }^{138}$ That a public authority was under a statutory duty to perform a task has been seen as precluding a "voluntary assumption of responsibility" for its performance. ${ }^{139}$ Essex County Council was under similar legal compulsion. The statutory National Curriculum for England requires that: "All schools must provide swimming instruction either in Key Stage 1 or Key Stage 2". State schools like Whitmore Junior School therefore have no choice but to provide swimming lessons. This aspect of Woodland fits uneasily with the whole notion of a "voluntary" assumption of responsibility. Essex runs schools because it has a public duty to do so, it had no choice whether to school Miss Woodland, and no choice under the National Curriculum whether to teach her to swim. (Equally, Basildon Council had no choice but to consider private operators for its leisure services; local authorities can operate facilities themselves only if this represents "best value". ${ }^{140}$ )

Tomlinson L.J. feared that recognising liability in Woodland might "chill" schools against providing wider educational experiences - since they have no control over outside premises and staff but would be accountable for their negligence. ${ }^{141}$ Lord Sumption stated that schools need not answer for "those to whom no control over the child has been delegated, such as bus drivers or the theatres, zoos or museums to which children may be taken by school staff in school hours". ${ }^{142}$ This might help assuage concerns that potential legal liability deters the

\footnotetext{
${ }^{134}$ Atiyah, "Contracts, promises, and the law of obligations" n.000 above 41.

135 Yepremian v Scarborough General Hospital (1980) 28 O.R. (2d) 494 per Blair J.A. (dissenting) (majority declined to recognise non-delegable duty).

${ }^{136}$ Ellis v Wallsend District Hospital (1989) 17 N.S.W.L.R. 553, 568-569.

${ }^{137}$ Cf. [2012] EWCA Civ 239; [2014] A.C. 537, [82] per Kitchin L.J.

${ }^{138}$ n.000 above. Cf. Spring v Guardian Assurance plc [1995] 2 A.C. 296 (Lord Goff).

${ }^{139}$ See Neil Martin Ltd. v Revenue and Customs Commissioners [2006] EWHC 2425 (Ch) at [97]; Rowley v Secretary of State for Work and Pensions [2007] EWCA Civ 598; [2007] 1 W.L.R. 2861 at [54]. Compare Nolan n.000 above, 283-284 (contrasting Customs v Barclays at [38] per Lord Hoffmann and at [73] per Lord Walker).

${ }^{140}$ Local Government Act 1999, Part I. (For health, cf. National Health Service (Procurement, Patient Choice and Competition) (No.2) Regulations 2013.)

${ }^{141}$ [2012] EWCA Civ 239 [57].

${ }^{142}$ Woodland [25] (3).
} 
provision of adventurous youth activities. ${ }^{143}$ But we may safely predict that Lord Sumption's obiter comments will be tested in future litigation. ${ }^{144}$ Ironically, there would be a much stronger argument that a school had voluntarily assumed responsibility for pupils' safety on a theatre visit (where Lord Sumption was at pains to rule out liability) which was organised on the school's initiative rather than obligatory under the National Curriculum. It is a relief that swimming lessons (at least) cannot be withdrawn because of schools' fears about liability after Woodland. But the statutory duty precluding that undesirable outcome makes "voluntary assumption of responsibility" untenable.

It may be socially desirable to hold state schools strictly liable for the negligence of anybody carrying out educational functions on their behalf. But inventing "assumptions of responsibility", or drawing parallels with contract that are unsustainable for fault-based tort liability, are not convincing ways to justify it.

\section{TORT AND THE BASELINE OF SAFETY: VICARIOUS LIABILITY FOR INDEPENDENT CONTRACTORS?}

Tort law is not a fault-based monoculture (albeit fault is generally seen as a good prima facie reason for liability). There are islands of strict liability (albeit seen as exceptional and requiring justification). Indeed, the continent of negligence harbours within it a vast empire of strict liability for the torts of others (vicarious liability). The true justification for vicarious liability is perennially controversial. But its practical importance cannot be in doubt. While tort remains theoretically based on individual responsibility, in practice a large proportion of tort liability is imposed on organisations (business corporations, public authorities) answering impersonally for their employees' torts. Despite its blatant inconsistency with notions of personal responsibility, vicarious liability attracts surprisingly few critics. Its "social convenience and rough justice" evidently exerts a wide appeal. ${ }^{145}$ In part because vicarious liability mostly avoids holding organisations "personally" liable for their "own" torts. Although such direct liability might sound desirable in principle it would necessitate rules to attribute the acts of natural persons to corporate abstractions, to decide whether an organisation was at fault "itself". Of course such theories are not beyond the wit of man, but historically they have been obscured by "anthropomorphic inquir[es]" and their "metaphysical shadows"; ${ }^{146}$ and even the modern "contextual" approach is scarcely free of difficulty. ${ }^{147}$ Vicarious liability performs an attribution function in a broad and simple way. ${ }^{148}$ The employer answers for all torts committed by employees in the course of employment. The possibility of direct liability of the organisation "itself" remains, but as noted above the very width of vicarious liability (the other route round the triangle) precludes that inquiry in most cases.

Business organisation today has placed this model under pressure. Vicarious liability is said, axiomatically, to apply to employees (only) and not to independent contractors. Once, such situations were less common and those that arose threatened to expand strict liability for individuals (the householder-client of a negligent plumber, etc). ${ }^{149}$ But when businesses frequently do, and public authorities typically must, outsource their operations to independent

\footnotetext{
${ }^{143}$ See Explanatory Notes to the Social Action, Responsibility and Heroism Bill (Government) (introduced in the House of Commons on 12 June 2014). See for an earlier attempt to tackle the same problem of perception: Compensation Act 2006, s.1.

${ }^{144}$ R. George (2014) 130 L.Q.R. 534.

${ }^{145}$ ICI v Shatwell [1965] A.C. 656, 685 per Lord Pearce.

${ }^{146}$ E. Ferran, "Corporate attribution and the directing mind and will" (2011) 127 L.Q.R. 239.

${ }^{147}$ Meridian Global Funds Management Asia Ltd. v Securities Commission [1995] 2 A.C. 500.

${ }^{148}$ See further R. Stevens, "Vicarious liability or vicarious action?" (2007) 123 L.Q.R. 30.

${ }^{149}$ Balfour v Barty-King [1957] 1 Q.B. 496.
} 
contractors, a troubling gap opens up. The Supreme Court in Woodland evidently thought it unacceptable that authorities would escape liability after outsourcing services to negligent contractors (absenting negligence in the outsourcing process). It has been suggested above that equal unease would arise irrespective of parallel contractual liability (no similar services provided for payment); the contract issue is ultimately a red herring. It is time to face openly whether vicarious liability, which has recently experienced more than one "William Ellis moment" by expanding beyond strict employer-employee relationships, ${ }^{150}$ could also extend to independent contractors.

Woodland, of course, provides the seed from which the revolution might grow. We have argued above that much of the Supreme Court's reasoning simply cannot be accepted. The analogy with contract is unconvincing and ultimately irrelevant; "voluntary assumption of responsibility" a transparent fiction. Yet the presence of unconvincing arguments does not necessarily mean the decision is wrong. As a matter of precedent it is here to stay, in any event. How broad are the implications? Woodland could inaugurate a specific rule of vicarious liability for contractors for the benefit of vulnerable groups (school pupils, hospital patients, etc). Protecting such persons has an especially appealing resonance as a general matter, ${ }^{151}$ and patients' "special need of care" was cited by Mason J as a reason for imposing exceptional "nondelegable duties" in his influential judgment in Kondis v State Transport Authority. ${ }^{152}$ Potentially though, this is a far-reaching basis for a supposedly exceptional rule. Is not every stranger (i.e. everyone who lacks "alternative means of protection") ${ }^{153}$ vulnerable to the financial consequences of a negligent contractor's impecuniosity? ${ }^{154}$ Even confining "vulnerability" to physical risks, this justifies the much-derided category of "ultra-hazardous activities" as readily as special weakness of claimants. ${ }^{155}$ For as Murphy says, vulnerability "comprises no more than the inverse of abnormal risk". ${ }^{156}$ Also, as discussed, Lord Sumption sought to preclude future extensions of liability to extramural activities beyond the direct physical control of school authorities. ${ }^{157}$ Yet there is no serious suggestion that schoolchildren become any less vulnerable in such situations - indeed with much "adventure activity" the opposite must be true.

Another possibility, canvassed already, ${ }^{158}$ is that Woodland is better seen as a special principle applicable to public authorities: these should not be able to contract out of the liabilities they would previously have born (qua master of servant-tortfeasors) by outsourcing the provision of public services. This might seem politically appealing to some. But there is no apparent basis for such a "preservation of liability" in the legislation enabling (and requiring) outsourcing of service-provision, nor (it seems) in general principles of administrative law. ${ }^{159}$

\footnotetext{
150 E n.000 above at [60] per Ward L.J. (referring to Viasystems Ltd. v Thermal Transfer Ltd. [2005] EWCA Civ 1151, [2006] QB 510, introducing a novel concept of dual employment).

${ }^{151}$ J. Stapleton, "The golden thread at the heart of tort law: Protection of the vulnerable" (2003) 24

Aust. Bar Rev. 135.

${ }^{152}$ n.000 above (cited Woodland at [19]).

${ }^{153}$ Stapleton n.000 above.

${ }^{154}$ Consider Gwilliam v West Hertfordshire NHS Trust [2002] EWCA Civ 1041; [2003] Q.B. 443.

${ }^{155}$ See Burnie Port Authority v General Jones Pty. Ltd.. (1994) 179 C.L.R. 520, [37] (cited Woodland at [20]; compare at [23] where Lord Sumption identifies vulnerability as one of the "defining features" of "nondelegable duty", having "put to one side" the "hazard cases").

${ }^{156}$ Murphy n. 000 above p. 381.

${ }^{157}$ n.000 above. (Consider also the limit placed on hospitals' (assumed) "non-delegable duty" in Farraj n.000 above.) ${ }^{158}$ pp.000 above.

159 Although N.B.: "a public authority cannot divest itself of its public powers or duties by entrusting performance to a contractor... [It] remains legally and politically accountable for their exercise... In principle, authorities should remain liable for compliance with public law norms whether a service is contracted out or delivered in-house" A.C.L. Davies, The Public Law of Government Contracts (Oxford
} 
Such arguments have not found judicial favour in the past: for example in $A_{v} M o D$, which raised the very question whether the Ministry's (alleged) non-delegable duty to patients could be sloughed off by its outsourcing medical care to other providers, instead of running its own military hospitals (it could). ${ }^{160}$ Similarly, Wright J. found nothing in the relevant legislation to displace the ordinary rule precluding liability for the torts of an independent contractor, when the Secretary of State had delegated functions to a privately-run immigration detention centre. ${ }^{161}$

In any event, outsourcing is hardly a phenomenon confined to public services. It originated in the private sector and was imported to the public realm in the hope of improving efficiency. The "problem" of an organisation outsourcing functions to independent companies instead of providing them in-house is just as likely to confront accident victims in the private context. Again therefore, the general question of vicarious liability for contractors is raised.

Space precludes an answer here. But the costs and benefits can be sketched. At a very simple level, victims would benefit from having a second, potentially solvent target (the client of the contractor-tortfeasor); whereas those clients would, obviously, lose out. But it is not simply a transfer between the groups (a zero-sum game). There is reason to think that extending vicarious liability to contractors would result in the widespread inefficiency of double insurance (two parties insuring against the same risk - a cost which benefits only the insurance industry). At present, one benefit of outsourcing a function is precisely that the risk of liability (for injuries created by the activity) is outsourced too. As Merkin and Steele report, it is normal for outsourcing contracts to oblige the contractor to carry public liability insurance against such risks - a clear recognition that the risk has been transferred. ${ }^{162}$ Of course the "outsourcer" does not need to insure against those same liabilities (given the classical common law rule). Should Woodland herald a general collapse of that rule however, it is plain that "outsourcers" would need to insure against those risks too. Hence the inefficiency. ${ }^{163}$ (In passing we can note that the same "double insurance" cost is not imposed in practice by (ordinary) vicarious liability for employees: simply, the employee is typically not insured, and does not need to be insured, because actions for damages against employees personally (rather than the vicariously liable employer) are extremely rare - and those that are brought have been controversial enough to lead to calls for legislative reversal, ${ }^{164}$ or spurred judges to extreme doctrinal innovation to protect the employee. ${ }^{165}$ In short, the position (de facto if not de jure) ${ }^{166}$ is that vicarious liability excludes the personal liability of employees. ${ }^{167}$ But nobody suggests that contractors should not remain liable in a Woodland situation-hence the double insurance problem.)

2008), 232, 239 (emphasis added). See Deregulation and Contracting Out Act 1994, s.72. Quaere whether this principle should extend to ordinary tort liabilities.

${ }^{160}$ n. 000 above.

${ }^{161}$ Quaquah v Group 4 and Home Office [2001] Prison L.R. 318. Cf. P.P. Craig, Administrative Law, $7^{\text {th }}$ ed. (London 2012), 119.

${ }^{162} \mathrm{n} .000$ above.

${ }^{163}$ It is worth emphasising again that whereas the Court of Appeal took notice of the insurance arrangements in denying the claim against the outsourcing local authorities, the Supreme Court simply ignored this in finding the "non-delegable duty": see n.000 above.

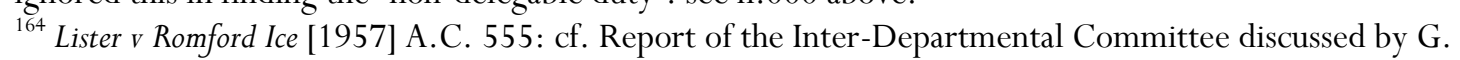
Gardiner (1959) 22 M.L.R. 652.

${ }^{165}$ Morris v Ford Motor Co [1973] 1 Q.B. 792.

${ }^{166}$ In London Drugs Ltd. v Kuehne \& Nagel [1992] 3 S.C.R. 299, La Forest J. would have made it de jure too.

${ }^{167}$ Cf. P. Morgan n.000 above (calling for the protective effect of vicarious liability to be extended to volunteer-tortfeasors). 
It might seem Scrooge personified to suggest that Miss Woodland's damages claim against the authorities should have been struck out - even pointing out that her rights of action against the lifeguard, the lifeguard's employer (the contractor), and their common insurer, remained unimpaired. But tort lawyers must beware another unsavoury literary archetype. ${ }^{168}$ Lady Bountiful is typically thought patronising, but when the riches bestowed belong not to the judges but the litigating parties, they commit the further sin of deriving pleasure "from the consciousness of spending others' money better than they would themselves". ${ }^{169}$ At the very least, any reform in the law must consider who pays the price. Generalising vicarious liability for contractors would of course impose costs on their clients ("employers") but also, less obviously, on society as a whole through the waste of double insurance. Given the prevalence of outsourcing, this would act as a drag not only private enterprise, but also increase the price of delivering public services (in crude terms, more of the finite revenue from taxation will be spent on insurance premiums, ${ }^{170}$ and so less on teachers, as a result of Woodland).

\section{CONCLUSION}

It may be helpful to summarise the argument.

1. The law can, and does, recognise duties to ensure that care is taken by whoever is carrying on a particular activity (as opposed to a personal duty to take care oneself). As a duty to ensure a certain outcome this is a (specific) form of strict liability.

2. Such duties are normal in contract. This reflects the general expectation that even promises to provide a measured service (e.g. "good and workmanlike" carpentry) guarantee that services of that quality will be provided. Promisors do not usually undertake to provide the service themselves: it is widely appreciated in many (if not most) contracts that they cannot. A fortiori they do not merely promise to take care personally to provide services of the stipulated standard (e.g. by carefully selecting those who are actually to do the work). A promisee is usually indifferent about who performs; what matters is what is performed (i.e. services of the stipulated standard). These points are rarely explicitly discussed, but are widely assumed for the allocation of liability in multi-party arrangements. The presumption fits the near-absolute liability for breach across the law of contract.

3. Duties to ensure that care is taken have exceptionally been recognised in tort under the misleading label "non-delegable duty" (which should ideally be discarded). But such duties are as anomalous within fault-grounded liability such as negligence as they are redundant in torts of strict liability. ${ }^{171}$ Even accepting that negligence is not the only tort and that strict liability retains a sporadically important role, ${ }^{172}$ a convincing reason is necessary to justify a strict duty to ensure that care is taken when, ordinarily, a defendant would not be liable in the absence of fault. Delegating performance to an apparently competent, carefully selected contractor ordinarily discharges a duty of care by performing it.

4. It has been proposed that a voluntary assumption of responsibility (i.e. to ensure that care is taken) justifies such a duty. The theory has received wide support and attractively identifies a species of tort liability analogous to contract. However, if taken seriously, "assumption of

\footnotetext{
${ }^{168}$ Farquhar, The Beaux' Strategem (1707).

${ }^{169}$ Campbell n.000 above.

${ }^{170}$ Or indeed on damages, for public authorities that choose to self-insure (e.g. the NHS).

${ }^{171}$ Consider the facts of Fletcher v Rylands (1866) L.R. 1 Ex. 265, 278.

${ }^{172}$ See Stevens n.000 above
} 
responsibility" would justify liability in very few situations (i.e. only when, without payment, a defendant willingly assumed such a strict, legally enforceable obligation). In practice, the concept has been discredited by frequent invocation in cases where there was neither express nor implied assumption, ${ }^{173}$ and/or nothing voluntary about it (including Woodland).

5. The Supreme Court in Woodland strove to avoid leaving a state school pupil, suing in tort, in a worse position when injured by an independent contractor than a private school pupil would be, suing in contract. But such distinctions are inevitable. Contract and tort doctrines differ fundamentally (e.g. on accrual of the cause of action), leading to different outcomes (e.g. on "preventive" and "loss of chance" damages). The subject matter of this article is another prominent example. Even more obviously (indeed tautologously), promisees will be in a better position when they negotiate and pay for a higher degree of protection through their contracts. Fine distinctions arise when identical services are provided both gratuitously (e.g. by public authorities) and for reward (under contract). Drawing such distinctions may seem invidious, but from a purely doctrinal perspective that is not a satisfactory reason for ignoring them.

6. In sum, it has been shown why duties to ensure care is taken fit easily into contract but only with great difficulty into tort; that the different approaches derive from fundamental features of contractual and tortious liability, especially the role of fault (and not merely "technical differences"); ${ }^{174}$ that the distinction cannot be ignored solely because it produces different (less generous) outcomes in tort cases compared with factually similar contract claims; that "assumption of responsibility" holds out some promise for principled bridging of the divide, but it has been more often abused than convincingly applied.

As the work of Atiyah and others has demonstrated, the position of the contract-tort borderline changes over time and stirs deep economic and political controversies. While coherence with the overall doctrinal structure of contract and tort is (it has been argued here) important, it cannot ultimately determine the economic/political questions that lie beneath the surface. The most influential contemporary counterblast to the expansion of tort has little traction upon the instant question. Giving commercial parties for free (i.e. through tort) obligations that they could have paid for by contracting has been heavily (and rightly) criticised. ${ }^{175}$ But the corollary is that absence of contract should not exclude tort liability when the claimant was "vulnerable" (i.e. not well placed to protect herself through a contract). ${ }^{176}$ If the contractual analogy in Woodland is in the end misleading, the absence of a contract still does not preclude wider liability in tort outside the commercial sphere.

Woodland, if correctly decided, should therefore be seen as establishing a level of protection that everyone is entitled to expect, irrespective of payment. ${ }^{177}$ Namely that organisations should be vicariously liable for the negligence of their contractors. This is the logical outcome of "contract envy" of the superior protection of injured private pupils or patients. The intuitive discontent, properly understood, relates to tort's inadequacy in an absolute sense, not just in comparison with potential rights under contracts. (Such a

\footnotetext{
${ }^{173}$ Consider Murphy n.000 above at 386: "the creation of an exceptional risk can be invoked to justify the imputation to the defendant of an 'assumed' responsibility if the defendant does not voluntarily undertake such a duty".

${ }^{174}$ Pace Lord Sumption n.000 above.

${ }^{175}$ pp. 000 above (and see further Esanda Finance v Peat Marwick Hungerfords (1997) 142 A.L.R. 750; Woolcock Street Investments v CDG (2004) 205 A.L.R. 522).

${ }^{176}$ Stapleton n.000 above (and see further Smith v Bush [1990] 1 A.C. 831; Bryan v Maloney (1995) 128

A.L.R. 163; Barclay v Penberthy (2012) 291 A.L.R. 608).

${ }^{177}$ Cf. Gold v Essex, n.000 above, p.297 per Lord Greene M.R.
} 
comparison proves too much since contracting consumers might always be better protected; yet courts have frequently affirmed limits on tort liability notwithstanding contract beneficiaries' greater rights.) Absenting a true voluntary assumption of responsibility, tort liability is imposed by law. Whether we discuss duties to ensure care is taken, "non-delegable duties", or vicarious liability (for contractors) ultimately matters little. But the third option would avoid the anomalies of the former, discussed above. It would focus attention on what seems to be the real question latent in this area: should organisations now answer for their contractors as well as their employees, when outsourcing is becoming ubiquitous? Considering the justifications for vicarious liability, and for traditionally limiting it to employees, will be necessary to answer this question. By contrast, the absolute liability of a promisor when a service fails to meet the contractually-defined standard provides little illumination for a law of torts which retains fault as its default standard of personal responsibility. 